WATER-LEVEL CHANGE

SEPTEMBER 1981-SEPTEMBER 1982

EXPLANATION

17 RISE IN WATER LEVEL

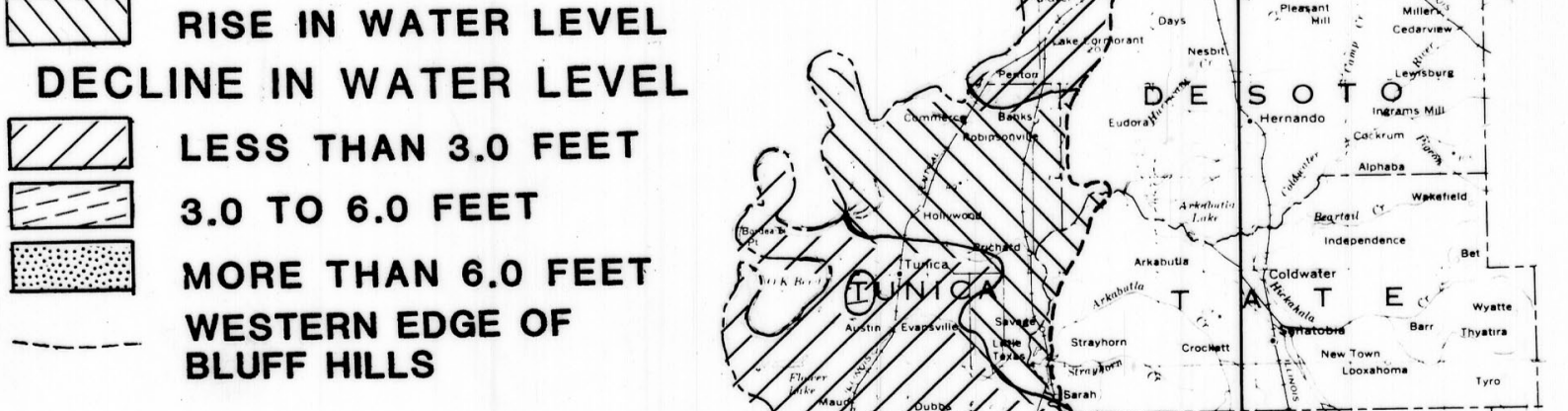
Bureau of Land and Water Resources
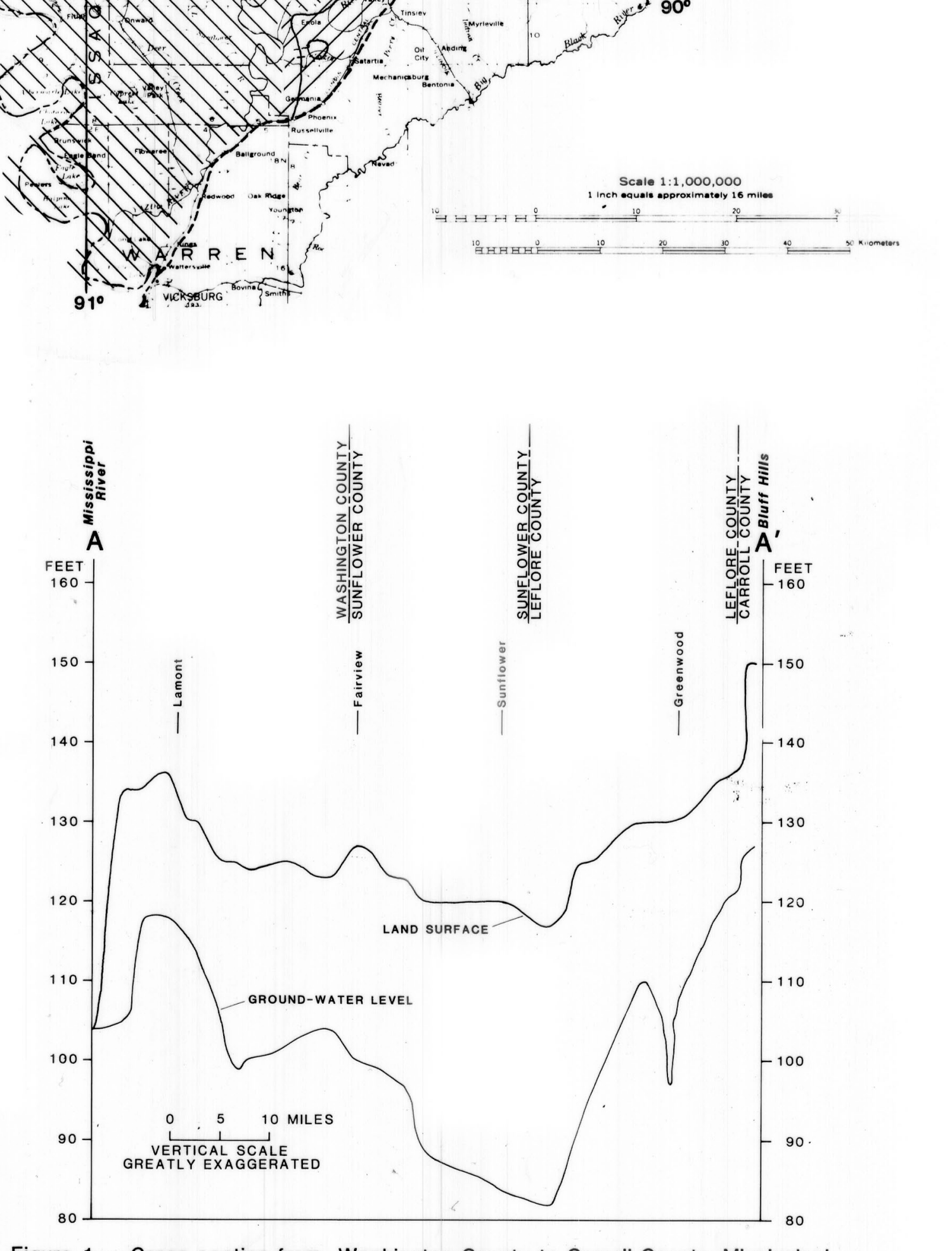

ADDITIONAL INFORMATION

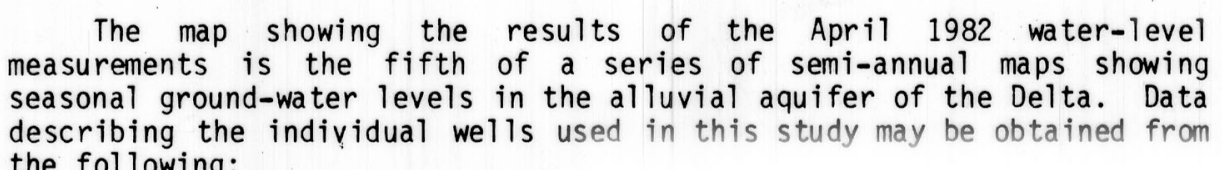
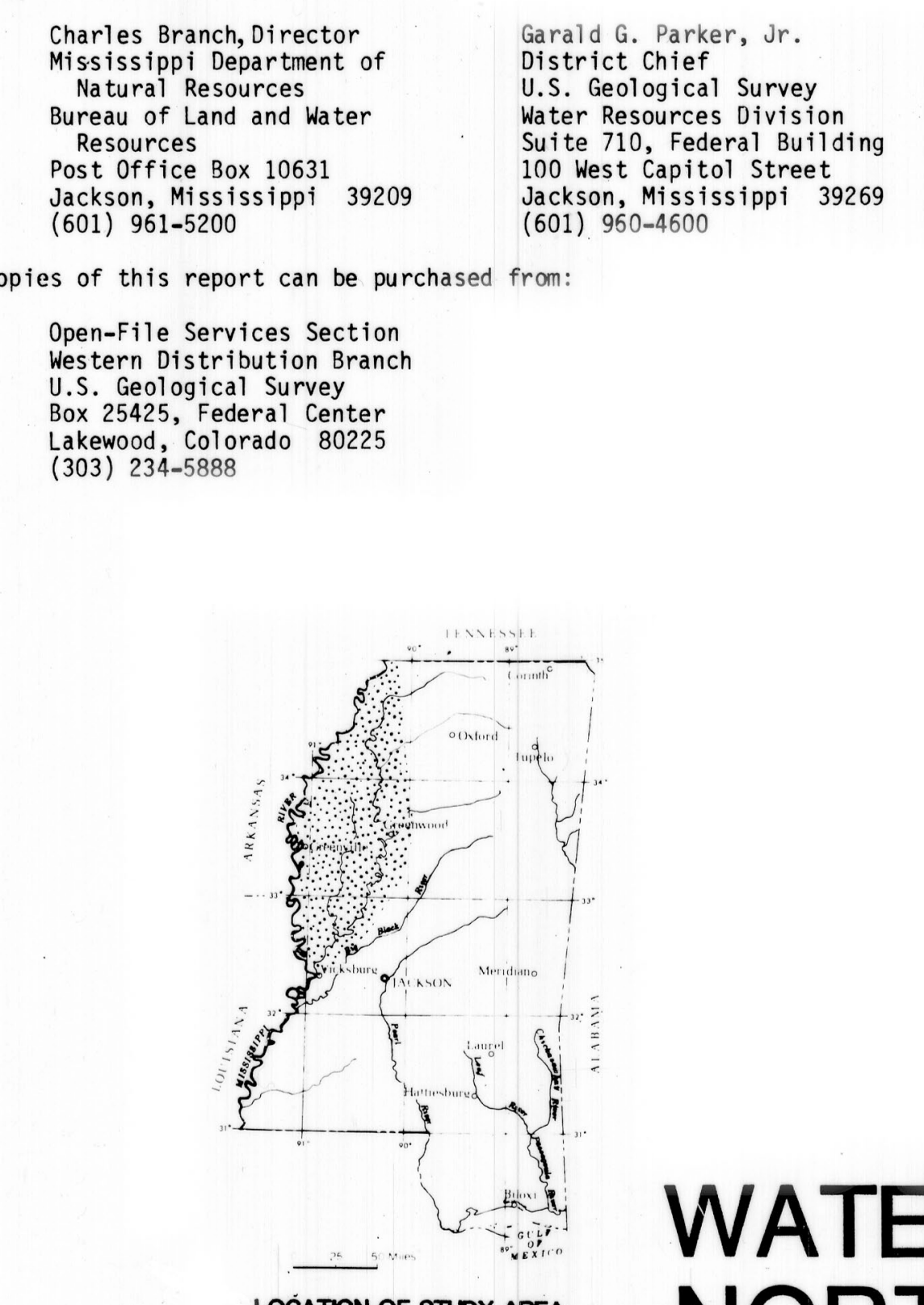
INTRODUCTION

The alluvial plain of the Mississippi River in northwestern
ssissippi includes about seven thousand square miles of farmland in the lower part of the Yazoo basin. The arear known locally as "the
Delta", is a nearly flat southward sloping surface characterized by

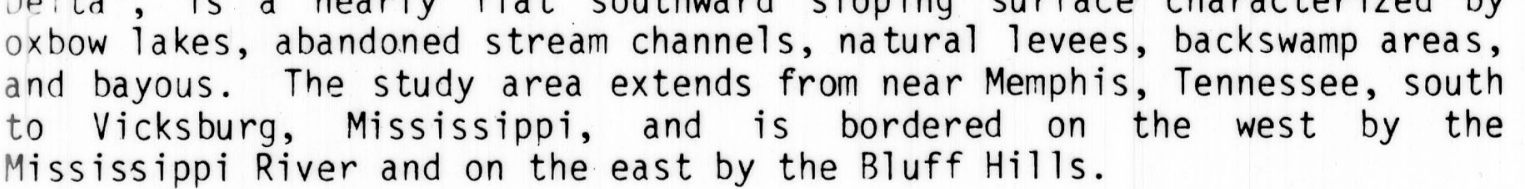
This report shows the altitude of ground-water levels and changes
in water-levels in the Delta. where large quantities of ground water are

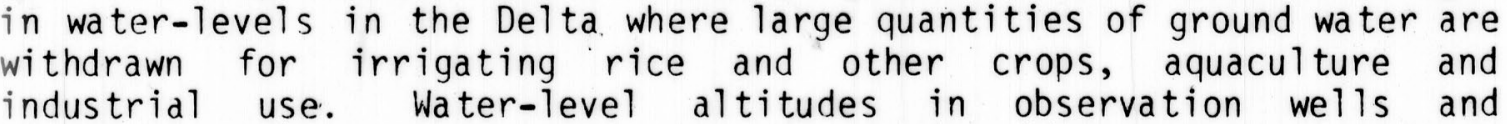
altitudes of some stream stages were used to determine water-level
altitudes shown on the water-level map. The depth-to-water map was
The

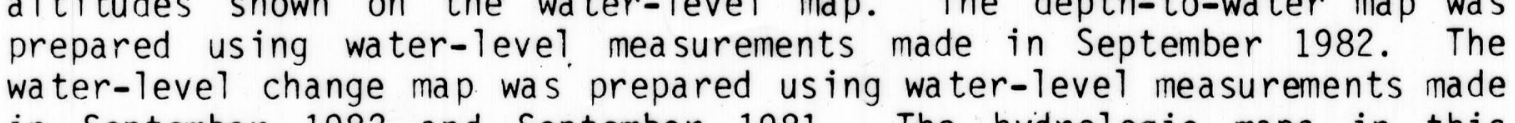
report were prepared by the U.S. Geological Survey in cooperation with neasurements made in about 500 wells in the alluvial aquifer in September 1981, Apr.i1 1982, and September 1982.

\section{ALLUVIAL AQUIFER} The alluvial aquifer is commonly composed of two parts. Clay,
silt, and fine sand make up the upper, less permeable part of the
aquifer, and sand and gravel make up the highly permeable lower part of
the aquifer. The aquifer which ranges in thickness from less than 50 feet to more than 150 feet, is thin near the eastern edge of the Delta
and in some areas along the Mississippi River. Because of the thickness and high permeability of the lower sand and gravel part of the aquifer,
the Mississippi River val ley alluvium yields large quantities of water to wells. Large, irrigation wells
per minute are common in the area.

The aquifer is recharged by the Mississippi River and streams that
flow through the Delta water levels in September 1982 may have resulted from higher stages of the Mississippi and Yazo Rivers. Progressively lower water leves in
the central part of the Delta may have resulted from continued drought
conditions from the sunnmer of 1980 through the summer of 1982 and . WATER-LEVEL CHANGE MAP SEPTEMBER 1981-SEPTEMBER 1982 The water-level change map shows the net change in ground-water
levels between September 1981 and September 1982 . Ground-water - 2 evels
generally rose in areas al ong the Bluff Hills, the Mississippi River and the lower part of the Yazoo River; areas not heavily punped for

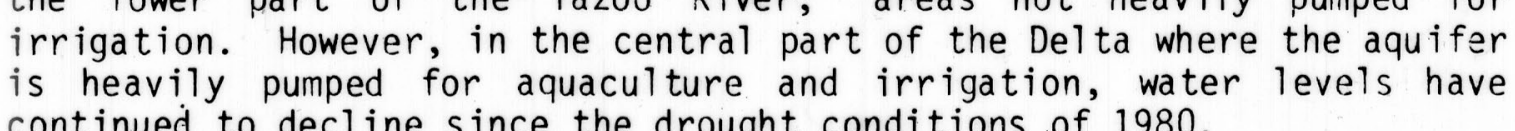
Of the 355 wells, measured in September 1981 and September 1982 ,
water levels declined in 204 well1s, rose in 150 well $1 \mathrm{~s}$, did not change in

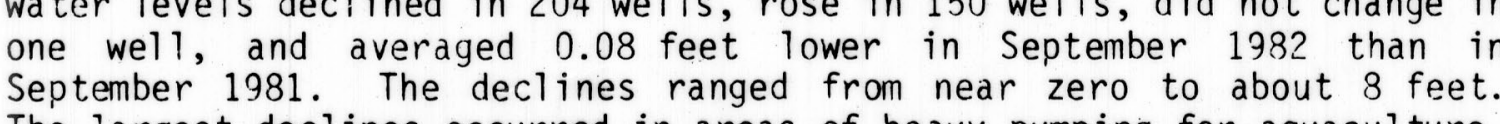

\section{WATER-LEVEL MAP} SEPTEMBER 1982

DEPTH TO WATER SEPTEMBER 1982

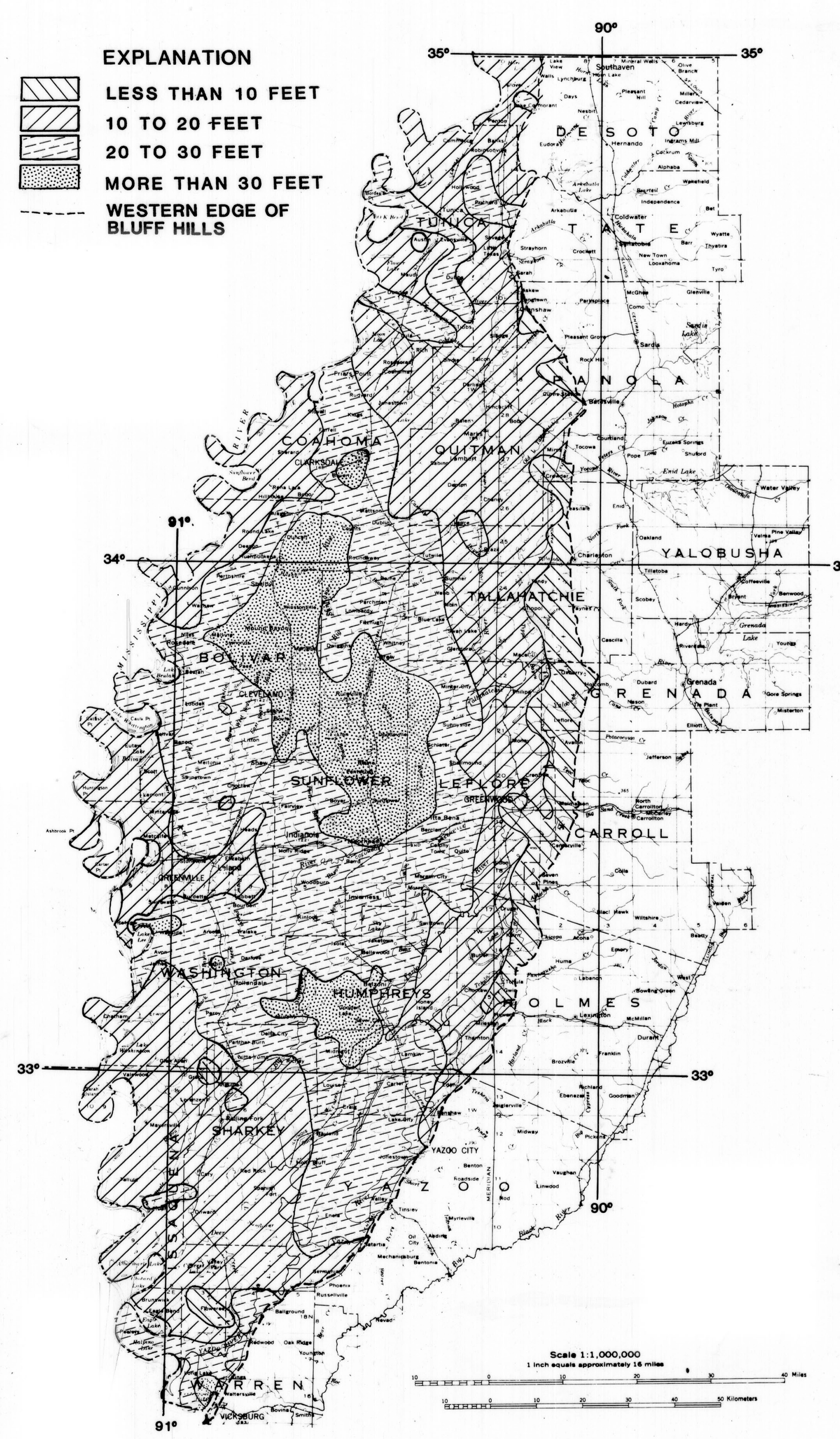

WATER-LEVEL MAP SEPTEMBER 1982

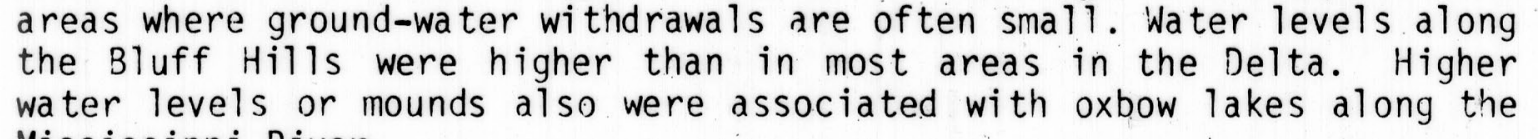
The cross section A-A', across washington, Sunflower, Leflore, and
Carrol1 Counties, shows water-level altitudes in the aquifer and in
selected wells in September 1982. The highest water-level altitudes

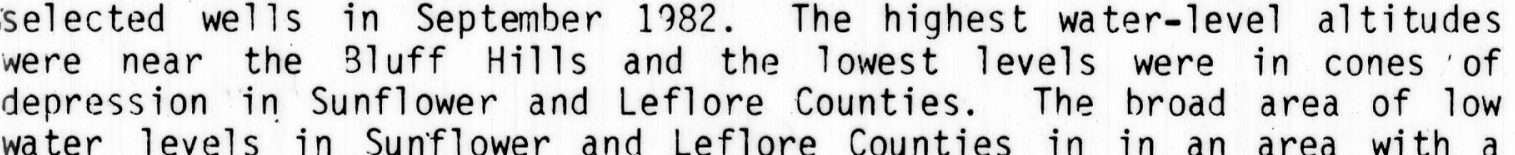
water levels in Sunflower and Leflore Counties in in an area with a
large concentration of wells. The cone of depression in the Greenwood
area is due to local pumping for cooling a municipal power-gerating DEPTH TO WATER

The depth to water map shows the depth to water below land surface near the end of the 1982 growing season. Water levels were generally
shallower near the Bluff Hills and the Mississippi River laver
level were generally concentrated in the central part of the Del ta near the Sunflower, River and in areas heavily pumped for rice farming and
aquaculture. Deep water levels in isolated areas probably reflect local SELECTED REFERENCES

ttandorff, J.M., and Leake, S.A., 1976, Nater for industrial and
agricultural development in Attala, Holnes, Humphrows Issar agricultural development in Attala, Hol mes, Humphreys, Issaquena,
Sharkey, and Yazoo Counties, Mississippi: Mississippi Research and
Development Sulletin, 49 p. Mis and

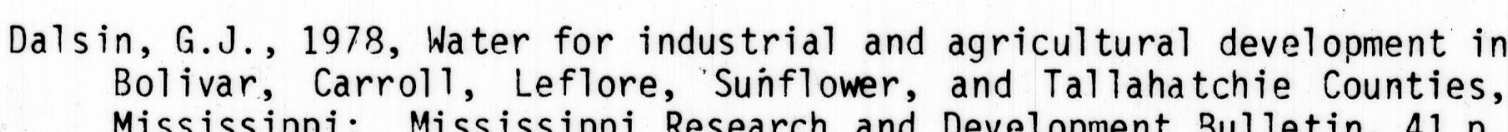
Oarden, Daphne, 1981, Water-level map of the Mississippi Delta al luvium
in northwestern Mississippi, April 1981: U.S. Geological Survey
Water-Resources Investigations 81-1123. 1982a, Water-level map of the alluvial aquifer, northwestern
Mississippi, September 1981 , I. G. Geological Survey
Water-Resources Investigations $82-574$. 1982h, Water-level maps of the al luvial aquifer, northwestern
Mississippi, Apri1 1982: U.S. Geological Survey Water-Resources

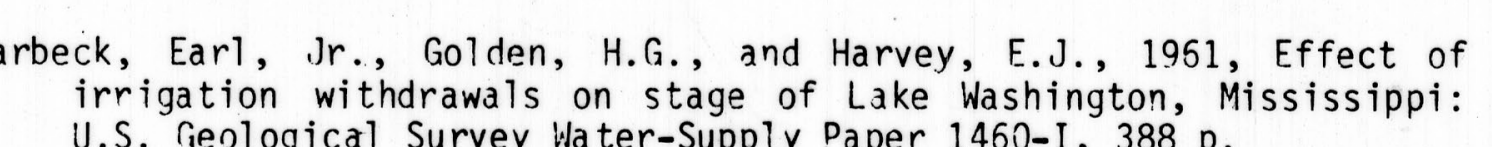
lor, R.E., and Thompson, F.H., 1971, Water for industry and
agriculture in Washington County, Mississippi: Mississippi
Research and Development Bulletin, 21 p. Wasson, B.E., 1980, Water-leve1 map of the Mississippi Delta all luvium in
northestern Mississippi, September 1980: Bureau of Land and Water
Resources Map $30-1$.

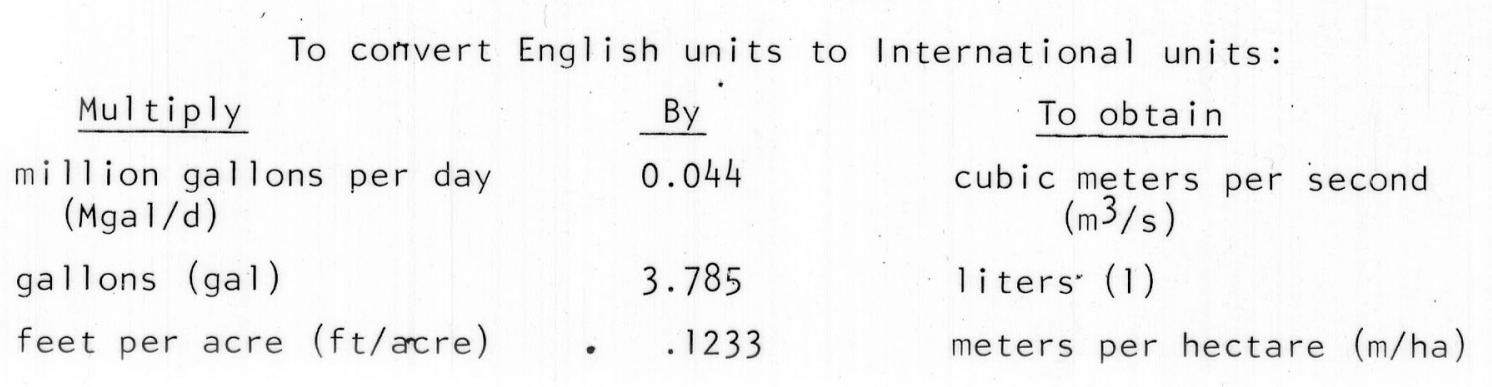

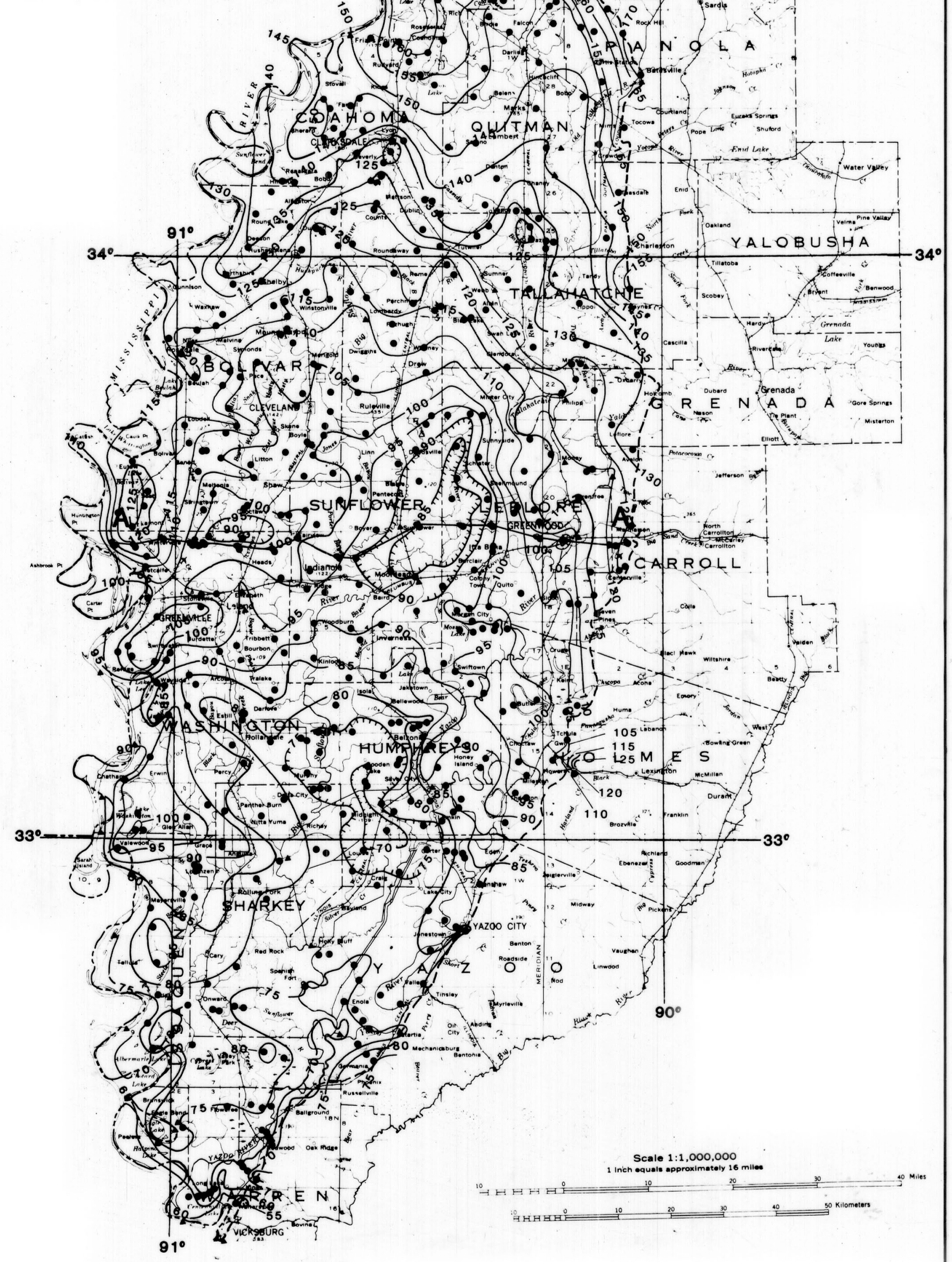

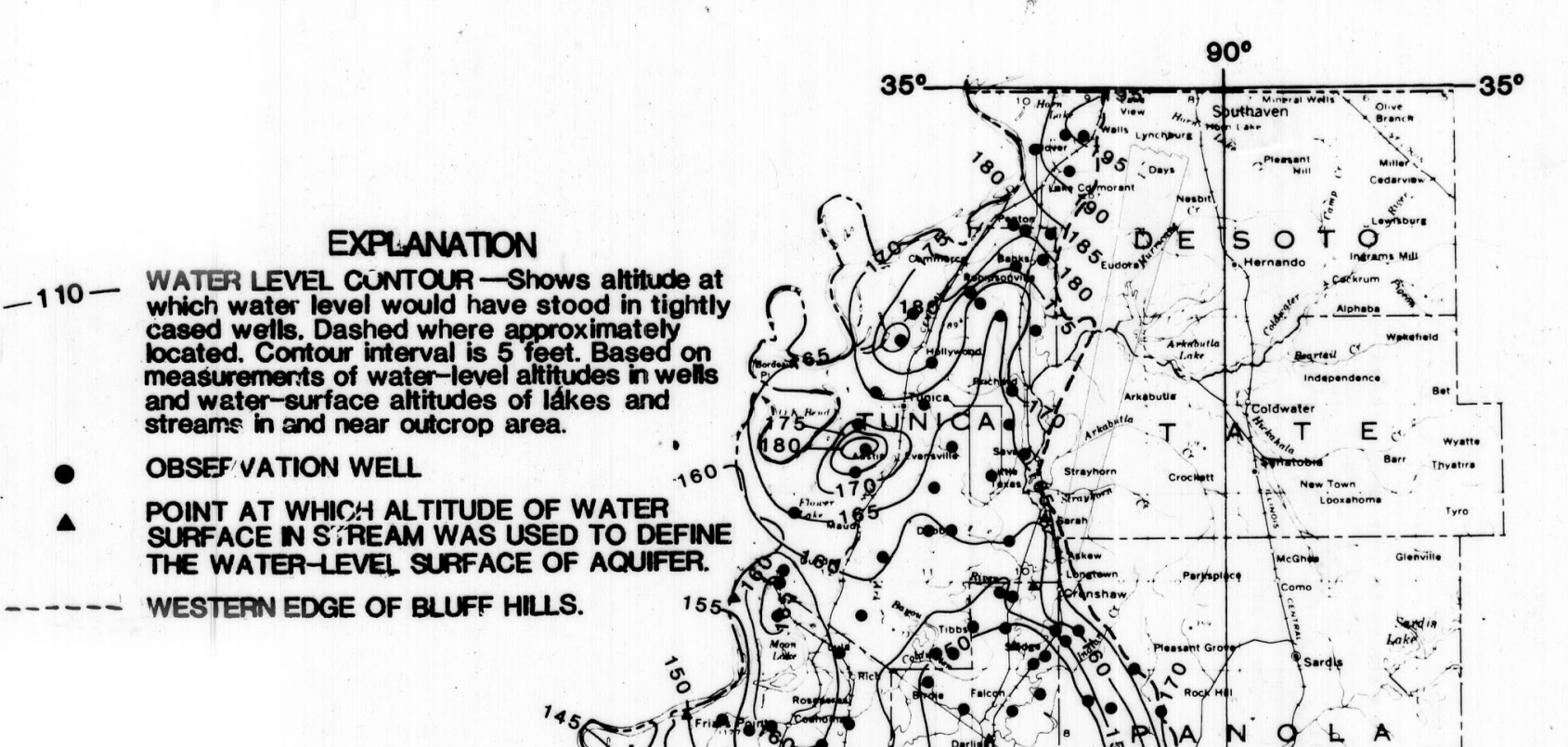

